\title{
CTAG1 Antibody
}

National Cancer Institute

\section{Source}

National Cancer Institute. CTAG1 Antibody. NCI Thesaurus. Code C129682.

Any immunog lobulin that recognizes cancer/testis antigen 1 protein. 